\title{
Quality Function Deployment Implementation Based on Kano Model An Application on Mobile Vendor Product Development
}

\author{
Oleh : Rusdiyantoro \& Yunia Dwie Nurcahyanie *)
}

\begin{abstract}
The severe competition in the market has driven enterprises to produce a wider variety of products to meet consumers' needs, a strategic business system allows more effective communication among different groups at dispersed locations to share ideas and access information needed for developing new products and executing innovative processes. The main function of mobile vendor product development is to develop an attractive system which ensures customer satisfaction. Therefore, one of the important topics of the system developments is to take customer requirements into consideration. Quality function deployment (QFD) has been widely used for numerous years; it is one of the structured methodologies that are used to translate customer needs into specific quality development. However, in the traditional QFD approach, each element's interdependence and customer requirements are usually not systematically treated. Additionally, the Kano model can effectively classify customer demand attributes, but to make Kano model more objective in the course of weighing.
\end{abstract}

Keywords: Product Product development; Quality function deployment; Kano model

\section{INTRODUCTION}

However, for companies which design the PLM systems, customer requirements are generally not treated systematically. Even if customer requirements are collected before the design phase, they tend to be disregarded and finally vanish during the construction phase. Because of the lack of attention paid to customer requirements collection at these stages, problems in terms of design ability, delays due to incomplete designs, misunderstandings of customer expectations, rework, etc. are observed. Consequently, how to improve functions and modules, and creating them during the PLM system development stages with customer requirements are necessary and indispensable. To clearly specify customer wants and needs, Quality Function Deployment (QFD) framework that is commonly discussed in the quality management literature can be used as a proactive approach to encounter quality issues instead of taking the passive approach of lunching customer complaints (Akao, 1990). The basic concept of QFD is to translate the desires of customer or voice of customer (VOC), into product technical requirements or engineering characteristics, and subsequently into parts characteristics, process plans and production requirements by using a chart called House of Quality (HOQ).

As competition for new markets and customers increases, level of customer satisfaction also became a key factor for long-term business success. Satisfied customers are loyal customers and ensure a lasting cash flow in the future. According to Reichfeld and Sasser (1990), a 5\% increase in customer loyalty can increase the profit of a business by $100 \%$ due to the fact that satisfied customers purchase the products more often and in greater quantities. Generally, satisfied customers are less price-sensitive and more inclined to spend more on products they have tried and tested. The Kano model of customer satisfaction can determine "attractive" or "must-be" requirements which can be used in the QFD matrix to assure that most critical needs are translated into the next phases of product development (Tan \& Shen, 2000). However, the selection of weights is very subjective.

\section{Literature review}

\subsection{QFD and its applications in information system}

The origins of QFD can be traced to Mitsubishi's Heavy Industries Kobe shipyard in Japan in the late1960s when QFD was first used to facilitate cross-functional product development process (Day, 1993). QFD is an overall concept that provides means of translating customer requirements into appropriate technical requirements for each stage of product development and production (i.e., marketing strategies, planning, product design and engineering, process development). The need for QFD was driven by two related objectives (Gonzalez, Quesada, Picado, \& Ecklman, 72 Jurnal Teknik WAKTU Volume 09 Nomor 01 - Januari 2011 - ISSN : 1412 - 1867 
2004). These objectives started with the user (or customers) of a product and ended with product producers. To satisfy the objective, the Voice of the Customer is translated into the

\section{*) Dosen Teknik Industri \\ Universitas PGRI Adi Buana - Surabaya.}

Voice of the Engineer through a matrix, which is named House of Quality (HOQ). Hauser and Clausing (1988), Day (1993), Fung, Chen, and Tang (2006) illustrated that the basic format of the HOQ consists of six sections: (1) obtaining customer attributes and their relative importance; (2) developing design requirements responsive to customer attributes; (3) planning matrix; (4) interrelationships between customer requirements and design requirements; (5) design requirement correlation; (6) action plan. QFD applications have many benefits in the reduction of information system design related problems (Govers, 2000). QFD can reduce information system development time, improve product quality and deliver products at a lower cost, and consequently can increase the market share (Kim, 1993). QFD can also facilitate continuous information system improvement with an emphasis on the impact of organization learning on innovation (Partovi \& Corredoira, 2002; Partovi, 2006). QFD has also been extended and modified to make it more comprehensive and applicable such as enhanced QFD (Clausing, 1994) and intelligent information system for QFD (Harding, Popplewell, Fung, \& Omar, 2001). Bossert (1991) and Sarkis et al. (1994) indicated that QFD was used to determine the expectations of the potential users of the information systems. Potential users included people who would be implementing, using,

\subsection{Kano model and its applications in QFD}

Kano, Seraku, Taka hashi, and Tsuji (1984) developed a model which has been used by others to categorize the attributes of the product or service based on how well they are able to satisfy customer requirements, for example, King (1995), CQM (1993), Clausing (1994), and Cohen (1995). As Fig. 1 shows, the extent to which a quality element is provided is indicated on the $x$-axis. The further the arrow moves towards the right, the greater the extent to which the quality element is provided, while the further the arrow moves towards the left, the less the left, the less the extent to which the quality element is provided. Customer satisfaction is indicated on the $y$-axis. The higher the arrow, the higher customer dissatisfaction will be; on the other handle the lower the arrow, the higher customer dissatisfaction.
Based on these axes, the following are the popularly named Kano customer requirement categories (see Fig. 1):

a. The must-be or basic quality element: customers believe that this quality is a necessity; when it is not present, customers will be dissatisfied.

b. The attractive quality element: when present, customers will be satisfied; yet when it is not present, customer would still accept without dissatisfaction.

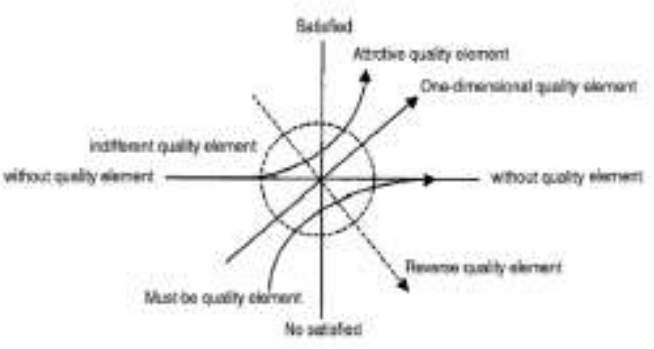

Fig. 1. Kano's two-dimensional quality model and five types of quality element.

a. The one-dimensional quality element: customers satisfaction is proportional to the level of fulfillment - the higher the level of fulfillment, the higher customer satisfaction, and vice versa.

b. The indifferent quality element: customers satisfaction will not be affected no matter whether this quality is provided or not.

c. The reverse quality element: customers will be dissatisfied if this quality element is provided; otherwise, they will be satisfied.

Two-dimensional quality was initially used in the development of the manufactured product quality (Kano et al., 1984) in a survey conducted on TV or decorative clocks. The survey results show that user conceptions of quality are not one-dimensional but two-dimensional; thus, the one-dimensional quality is unable to cover user quality conceptions. The Kano model has been applied not only to new product development (Matzler \& Hinterhuber, 1998) but also to new service creation (NSC) (Bhattacharyya \& Rahman, 2004). The importance of the Kano model is that it involves little mathematical computation and relevant information can be quickly obtained. Recently, this technique has been applied to the development of a variety of online services, such as web site (Zhang \& von Dran, 2001), internet community (Szmigin \& Reppel, 2004), and online ticketing (Nilsson- Witell \& Fundin, 2005). Sireli, Kauffmann, and Ozan (2005) applied a similar methodology to cockpit weather information system (CWIS) design.

Additionally, in the QFD literature, the Kano model is applied by assigning weights to 
different customer attributes. Islam and Liu (1995) indicated that customer needs can be divided into three subgroups, i.e., basic, onedimensional and excitement. For each requirement, the raw importance is adjusted by multiplying a weight that is calculated by an analytic hierarchy process. Similarly, using the dual importance grid, Robertshaw (1995) classified the type of Kano element and suggested that customer needs should be re-prioritized: the first priority is to deliver what is expected; the second is what is specified; the last is to provide the attractive elements. Gerson (2003) showed a modified Kano method to determine the degree to which an attribute is considered attractive or must-be by customers and how to integrate into the planning matrix of the QFD. Tan, Tang, and Forrester (2004) analyzed customer satisfaction based on the Kano model and pointed out the importance of product innovation in exceeding customer satisfaction.

Table 1 The traditional Kano questionnaire

\begin{tabular}{|c|c|c|c|c|}
\hline like & must be & $\begin{array}{r}\text { neu- } \\
\text { tral }\end{array}$ & live with & dislike \\
\hline $\begin{array}{l}\text { Do you comfortable enough } \\
\text { with your mobile vendor, is it } \\
\text { has enough space? } \\
\text { Do you feel not comfortable } \\
\text { enough with your mobile ven- } \\
\text { dor, and it is not has enough } \\
\text { space? }\end{array}$ & & & & \\
\hline
\end{tabular}

Table 2 Customer requirements category compared with tradional Kano

\begin{tabular}{lc}
\hline \multicolumn{1}{c}{ PRODUCT REQUIREMENT } & CATEGORY \\
\hline comfort space & M \\
unsharp table edge & A \\
reliability & M \\
easy move and replace & $\mathbf{O}$ \\
easy instalation & $\mathbf{M}$ \\
space versatible & $\mathbf{O}$ \\
space save & $\mathbf{O}$ \\
strong plywood & $\mathbf{I}$ \\
fit to environment design & $\mathbf{I}$ \\
fit to work place & $\mathbf{I}$ \\
drawer & $\mathbf{M}$ \\
cabinet & $\mathbf{M}$ \\
space for gas tube $3 \mathrm{Kg}$ & $\mathbf{A}$ \\
space for washing activity & $\mathbf{O}$ \\
space for enterntaiment & I \\
space for trash (wet) & $\mathbf{M}$ \\
space for trash (dry) & I \\
tidy cable arrangement & $\mathbf{O}$ \\
adjustable height & $\mathbf{A}$ \\
layout adjust & I \\
comfort activity & A \\
\hline
\end{tabular}

\section{Conclusion}

With the rapid developments in science and technology, customer requirements regarding products are constantly changing. Therefore, from the standpoint of system designers, it is obligated to maintain constant contact with customers, strive to comprehend changes in customer needs, and attempt to satisfy those needs, if it is desired to be in an unchallengeable position in the severe market competition. Accurate analytical methods are required to help designers understand current information on customer requirements and ob- tain the future requirement prediction information. This study describes a method for more objectively analyzing customer requirements and thus enabling the manufacture of products that meet customer demands. As a customer-oriented, QFD involves numerous data from both customer and QFD team members. Depending on their perspective background, people give information about their personal performances in many different ways. As the determination of CR priorities is the key concept in QFD, we believe that greater emphasis has to be placed on analyzing and merging individual assessments in different formats in order to provide a systematic decision procedure for system design within the QFD process, which has been traditionally based on expert opinions.

For improving the weaknesses of the classical QFD, the contributions of this study primarily have the following focuses: first, the questionnaire design was conducted using the Fuzzy linguistic method for more accurately verifying customer requirements. Upon understanding customer requirements, these requirements were simultaneously categorized with the aid of the Kano model. If the customer requirements were considered attractive, mustbe, or one-dimensional, it indicated that it should be listed as design item with top priority during the system development process. On the contrary, if it was classified as the indifferent or reverse attribute, the development could be postponed or removed under the circumstances where the development costs and cus- 
Rusdiyantoro \& Yunia Dwie Nurcahyanie : Quality Function Deployment Implementation Based on Kano Model An Application on Mobile Vendor Product Development

tomer satisfaction were taken into account

tion and system.

and; second, with regard to the system func-

\section{REFERENCES}

Akao, Y. (1990). Quality function deployment: Integrating customer requirements into product design. Translated by Glenn Mazur Cambridge. MA: Productivity Press, pp. 1-15.

Belhe, U., \& Kusiak, A. (1996). The house of quality in a design process. International Journal of Production Research, 34(8), 2119-2131.

Bhattacharyya, S. K., \& Rahman, Z. (2004). Capturing the customer's voice, the centerpiece of strategy making: A case study in banking.European Business Review, 16(2), 128-138.

Bossert, J. L. (1991). The quality function deployment: A practitioner's approach. Milwaukee, WI: ASQC Quality Press.

Burden, R. (2003). PDM: Product data management, Resource Publishing.

Clausing, D. (1994). Total quality development - A step by step guide to world-class concurrent engineering. New York: ASME Press.

Cohen, L. (1995). Quality function deployment: How to make QFD work for you. MA: Addison-Wesley.

CQM (1993). A special issue on Kano's methods for understanding customer-define quality, The Center for Quality of Management. Journal, 2.

Day, R. G. (1993). Quality function deployment linking: A company with its customers Milwaukee. USA: Springer.

Fung, Y. K., Chen, Y., \& Tang, J. (2006). Estimating the function relationship for function deployment under uncertainties. Fuzzy Sets and Systems, 157(1), 98-120.

Gerson, T. (2003). Develop of customer needs in the QFD using a modified Kano model. Journal of the Academy of Business and Economics.

Gonzalez, M., Quesada, G., Picado, F., \& Ecklman, C. (2004). Customer satisfaction using QFD: An e-banking case. Managing Service Quality, 14(4), 317-330.

Govers, P. M. (2000). QFD is not only a tool but also a way of quality management. International Journal Production Economics, 7(1), 151-159.

Grieves, M. (2005). Product lifecycle management. Driving the next generation of lean thinking. McGraw-Hill.

Halbleib, L., Wormington, P., Cieslak, W., \& Street, H. (1993). Application of quality function deployment to the design of a lithium battery. IEEE Transactions on Components, Hybrids, and Manufacturing Technology, 16(8), 802-807.

Hartmann, G. (2005). Product lifecycle management with SAP: The complete guide to my SAP PLM strategy. Technology and best practices. SAP Press.

Harding, J. A., Popplewell, K., Fung, Y. K., \& Omar, A. R. (2001). An intelligent information framework relating customer requirements and product characteristics. Computers in Industry, 44(1), 51-65.

Hauser, J. R., \& Clausing, D. (1988). The house of quality. Harvard Business Review, 66(3), 63-73.

Hsu, H. M., \& Chen, Y. C. (2001). A Fuzzy reasoning based diagnosis system for control charts. Journal of Intelligent Manufacturing, 12(1), 57-64.

Islam, A. \& Liu, M.C. (1995). Determination of design parameters using QFD. Transactions from the 7th Symposium on Quality Function Deployment, Novi, MI, 61-74. 
Kano, N., Seraku, K., Takahashi, F., \& Tsuji, S. (1984). Attractive quality and must-be quality. The Journal of the Japanese Society for Quality Control, 14(2), 39-48.

Kim, K.J. (1993). Fuzzy multi-criteria methodologies and design support system for quality function deployment. Unpublished PhD thesis, Purdue University.

King, B. (1995). Designing products and services that customer wants. Productivity Press.

Lasala, K. (1994). Identifying profiling system requirements with quality function deployment. In: Proceedings of the fourth annual international symposium of the national council on systems engineering. August 10-12, San Jose, CA (Vol. 1, pp. 249-254).

Liles, D. H., \& Sarkis, J. (1995). Using IDEF and QFD to develop an organizational decision support methodology for the strategic justification of computer-integrated technologies. International Journal of Project Management, 13(3), 177-185.

Liu, X. F. (2001). Software quality function deployment. IEEE Potentials, 19(5), 14-16.

Matzler, K., \& Hinterhuber, H. H. (1998). How to make product development projects more successful by integrating Kano's model of customer satisfaction into quality function deployment. Technovation, 18(1), 25-38. 